\title{
СЕНС ЖИТТЯ У КОНТЕКСТІ \\ ВІДЧУТТЯ ЗАДОВОЛЕНОСТІ ЖИТТЯМ
}

УДК: $159.923+128$

\section{Чуйко Галина Василівна}

Кандидат філологічних наук, дочент, дочент кафедри психології Чернівещького нащіонального університету імені Юрія Федьковича, Чернівці (Україна)

\begin{abstract}
Анотація. Стаття присвячена теоретичному та емпіричному вивченню феномену задоволеності життям та його зв 'язку з пережсиванням людиною осмисленості власного життя.

Зазначено, щуо поняття задоволеності життям поєднує когнітивний та емоційний аспекти суб'єктивної оцінки людиною ступеня відповідності ї̈ життя бажаному $і$ може сприйматися як екзистенційна изінність, щзо надає життю людини сенс.

Обтрунтоване положення про наявність зв'язку між відчуттям задоволеності життям та усвідомленням його сенсу.

Зроблений висновок, щуо задоволена життям людина живе з відчуттям щуастя від успішності реалізаџії своєї мети та наповненого сенсом життя, вірячи у справедливість світу та власну удачливість, базуючись на достатньому рівні власних життєвих ресурсів $і$ здатності впливати на подї свого життя та керувати ним.
\end{abstract}

Ключові слова: задоволеність життям, щзастя, сенс життя, благополуччя, мета, цุінність.

Постановка проблеми і актуальність дослідження. Те, що людині потрібно не просто жити, але й отримувати задоволення від життя, стверджували ще давні філософи, розмірковуючи про призначення людини у світі, тоді як у психологію ця ідея проникла відносно недавно: разом зі спрямуванням науки у позитивне русло та висновком щодо розумін- ня факту, що наукових робіт, які стосуються негативних переживань і «темних» сторін життя людини, в кільканадцять разів більше, ніж тих, що пов'язані з аналізом позитивних моментів життєвого шляху особистості.

Появу поняття задоволення життям можна пов’язувати з іменем Епікура, який переконував, що людина народжена для щастя $\mathrm{i}$ 
задоволення, а саме задоволення мудро розумів не стільки у чуттєвому сенсі, скільки як свободу від тілесних страждань (хвороб) і душевних мук. Проте, для усвідомлення справедливості та значимості висновку філософа потрібен життєвий досвід чи мудрість, або й те, й інше. Більшості ж людей для відчуття задоволення життям необхідно значно більше: досягнення бажаних цілей, самоздійснення, peaлізація життєвих цінностей і сенсу, навіть просто задоволення багатьох потреб: духовних і матеріальних, наявних, майбутніх і віртуальних, число яких по мірі їх задоволення збільшується.

Аналіз досліджень і публікацій. Насправді, питання благополучного і повноцінного життя людини завжди хвилювало психологію, проявляючись в тій чи іншій мірі чи формі в кожному її напрямку чи школі. Проте 3 часом з'являються психологи, яких ця проблема захоплює: Н. Бредберн, Е. Дінер, К. Ріфф, М. Селігман, М. Аргайл, Б. С. Братусь, К. О. Абульханова-Славська, Д. О. Леонтьєв, В. Е. Чудновський, К. В. Карпінський, Н. В. Паніна та ін. Але й досі систематизоване і цілісне уявлення про феномен задоволення життям у науковому обігу відсутHe.

Мета цієї статті - проаналізувати теоретичні аспекти проблеми життєвого сенсу та задоволення життям і дослідити ступінь (рівень) і особливості переживання задоволення життям студентів - майбутніх психологів.
У психологічній енциклопедії та словнику визначення поняття «задоволеність», як на нас, незавершене і неточне: «задоволеність (англ. satisfaction) - суб'єктивна оцінка якості тих чи інших об’єктів, умов життя і діяльності, життя в цілому, стосунків з людьми, самих людей, у тому числі і самого себе (самооцінка)» [14], - зазначимо: задоволення - це не будь-яка оцінка, а саме позитивна.

За Р. Лукасом і Е. Дінером, автором поняття «суб'єктивне благополуччя», яке в значній мірі, на його думку, відповідає поняттю «щастя», задоволеність життям - когнітивний компонент відчуття благополуччя, що відображає «рефлексивне судження людини про те, що її життя та його обставини складаються добре» [19]. Причому людина, оцінюючи, наскільки вона вдоволена життям, орієнтується на різні стандарти, співвідносячи їх 3 тим, що вона сама (суб'єктивно) вважає найбільш важливим у житті.

Йому вторить і М. Аргайл, згідно якого, «щастя можна розглядати як усвідомлення своєї задоволеності життям чи як частоту й інтенсивність позитивних емоцій» [3].

Але «задоволення» - це процес і результат переживання суб'єктивної оцінки успішності життя і функціонування особистості, і ця оцінка, як на нас, не $є$ виключно когнітивною, адже це не лише знання і розуміння людиною життєвої ситуації у форматі конкретного часового періоду, це в більш значній мірі й емоційна оцінка її як позитивної (радісної, ба- 
жаної) з точки зору самої людини. Тому закономірно, що багато вчених пов'язують відчуття задоволеності життям з емоційною сферою особистості.

Так, Н. В. Паніна тлумачить задоволеність життям як найбільш загальне уявлення людини про психологічний комфорт, який включає: інтерес до життя, рішучість, цілеспрямованість, послідовність у досягненні життєвих цілей, узгодженість між поставленими та реальними цілями; позитивну оцінку власних якостей і вчинків; загальний позитивний фон настрою, зазначаючи, що основним складником індексу життєвої задоволеності є емоційна складова [12].

Т.В. Углова визначає задоволеність життям як «суб'єктивну оцінку власного життя в цілому (умов життя і діяльності, досягнень, стосунків $з$ людьми і т. ін.), яка супроводжується приємними, радісними емоційними переживаннями» [13].

Р. М. Шаміонов - як суб'єктивне емоційно-оціночне ставлення, що має спонукальну силу, яка сприяє дії, пошуку, керуванню внутрішніми та зовнішніми об'єктами, складне, динамічне, соціально-психологічне утворення, в основі якого лежить інтеграція когнітивних і емоційно-вольових процесів [18].

Визначення поняття «задоволеність» у психологічному словнику за редакцією П. С. Гуревича як «оптимального стану людини, що виникає при відповідності потреб особистості з наслідками та результатами власної діяльності, досягненнями, характером взаємодії із соціальним оточенням, ... в результаті відповідності потреби самовираження, способів самореалізації та реальних досягнень, ... стосується перш за все найбільш значимих для особистості сфер іiі життєдіяльності...» [10, с. 702], за змістом, на нашу думку, цілком можна віднести до поняття «задоволеність життям».

Мотивуючи тим, що «задоволеність життям - складне, комплексне поняття, що акумулює множину факторів і аспектів, кожен 3 яких $є$ у значній мірі самостійним явищем» [4], дослідники прагнуть виявити ці фактори. Зокрема, Є. В. Балацький, намагаючись «сформувати максимально повний склад факторів, що впливають на задоволеність життям», виділяє аж 12 факторів (які, на його думку, «покривають всі три базові інстинкти» [4]: самозбереження, продовження роду та самореалізації, - що водночас $є$ «базовими людськими цінностями»), які, як на нас, не є власне факторами, а, скоріше, суб'єктивними причинами відчуття задоволеності життям, 3 іншого боку, цілком об’єднуються у 2 з виділених автором факторів: «досягнення поставлених цілей» і «комфортне середовище існування».

Попередньо розглянувши варіанти різних учених щодо груп факторів, які визначають задоволеність життям, Н. В. Андрєєнкова створює власну модель, що «може пояснити $37 \%$ різниці у задоволеності людей своїм 
життям» [2, с. 213] і підводить до висновку, що цей феномен залежить переважно від «соцієтальних умов і змін в політичній, економічній і соціальній сфері життя країни» [2, c. 190], тоді як особистісні фактори, на думку науковця, виявляються (вважаються) менш значимими.

На нашу думку, не варто як переоцінювати вплив зовнішніх факторів на відчуття людиною задоволення від життя, так і недооцінювати значення внутрішніх факторів у цьому процесі: адже важливі тут не «соцієтальні» фактори самі по собі, як об'єктивна реальність, а те, як їх сприймає людина, наскільки вони виявляються суб'єктивно значимими для неї.

Виклад основного матеріалу. На нашу думку, задоволення життям - поняття в значній мірі суб'єктивне (комусь для відчуття задоволення потрібно мінімум, іншій людині - все й одразу), як за якістю, так і за тривалістю: досить часто той, кому для задоволення життям потрібно максимум, отримавши бажане, швидко втрачає почуття задоволення у незадоволеному прагненні отримати ще більше - і цей стан перманентний. Тоді як той, для кого відчуття задоволення життям (як «промінчик світла у темному царстві» сірої буденності) - лише момент, для якого потрібна хоча б одна вдала обставина чи радісна подія, і не обов'язково у власному житті, зберігає у пам'яті цю мить переживання задоволеності життям і відчуття стану благополуччя ще дуже тривалий час.

Але задоволення життям не постійний стан протягом усього життя, це переживання зумовлюється певними подіями. Тобто можна бути задоволеним життям в цілому, але не бути задоволеним цілим (усім) життям (всіма його подіями і діючими особами); людина також може відчувати задоволення у певній життєвій ситуації. Додамо, що якщо мова йде про задоволення від процесу і результату життя (життєвого шляху), можна говорити як про наявність чи відсутність цього задоволення, так і про його міру.

Задоволення у житті людина може почувати від зробленого (хоча, не робити чогось, утримуватися від дії - може принести не менше задоволення) чи досягнутого (пережитого; успіхів у діяльності; певного рівня саморозвитку чи самоздійснення), причому і процес, і результат тут мають бути життєво важливими для людини - мати екзистенційну цінність. А це, в свою чергу, може стосуватися не лише безпосереднього виконання певної роботи, але й діяльності і поведінки людини в цілому. Об’єднуючим моментом тут виступає мета: зроблене чи досягнуте приносить відчуття задоволення життям лише у разі «співпадання» із життєвою метою людини, яку вона початково поставила. Тобто задоволення життям - це результат вдалої реалізації людиною її життєвої мети (стосовно певного періоду життя - життєвих цілей), яка сприймається як надважлива екзистенційна цін- 
ність, життєвий сенс.

В. Франкл роз'яснював, що прагнення до задоволення (чи щастя) не може бути сенсом життя, це, як і самореалізація, «побічні продукти» здійснення сенсу [15]. Звичайно, мова йде про «задоволення» у розумінні 3. Фрейда, проте поєднання поняття «задоволення» із «життям» (життєвим шляхом) не позбавляє позитивного емоційного переживання того, що відбувається у житті людини в цілому. Та, згідно поглядів Франкла, і задоволення життям вважатиметься виключно таким «побічним» продуктом реалізації життєвого сенсу. Проте, цілком очевидно, що люди прагнуть щастя і задоволення від життя, і саме у досягненні цього бачать сенс не лише власного життя (в цілому), але й сенс життєвих ситуацій, кожного моменту життя.

На нашу думку, задоволення життям може претендувати на те, щоб сприйматися як сенс життя не лише для гедоністично чи евдемонічно спрямованої особистості, а навіть у контексті поглядів Франкла. Адже задоволення життям можна вважати екзистенційною цінністю як категорії цінностей творчості (творче ставлення до роботи може приносити людині задоволення не лише від процесу та результатів самої роботи, але й від життя в цілому, якщо роботу та кар'єрний ріст людина цінує понад усе у житті), так і цінностей переживання (одними - від безмежної любові, іншими - від всеохоплюючої ненависті), тільки третя група екзистенційних цінностей (за Фра- нклом), цінності ставлення до страждань, може суперечити переживанню задоволення життям, хоча й не для всіх людей.

В. Франкл цитує Ф. Ніцше, що, якщо в людини $\epsilon$, навіщо жити, то вона витримає будь-яке «як» [15], тобто, якщо є сенс життя, то людина витримає майже будь-які його умови. Отже, сенс - це важлива умова, щоб жити, але навряд чи за «будь-яких» умов людина буде переживати задоволення від життя. Тобто наявність сенсу - важлива, але не єдина передумова жити, не менш важливо переживати емоційне задоволення від екзистенційної насиченості життя.

За Р. Меєм, для людини особливо важливий результат, «майбутній час: що вона буде являти собою в найближчому майбутньому» [8], якою вона стане, реалізувавши свої потенційні можливості, яким стане іiі буття, пройшовши процес становлення. Але, чи важливе у цьому випадку теперішнє відчуття задоволення/незадоволення життям? На нашу думку, логічним буде припущення, що саме незадоволення існуючим (наявним життям) «запускає» розвиток буття у напрямку становлення у майбутньому.

Зазначимо також, що не лише усвідомлення сенсу, згідно Р. Мея, приходить до людини перед розумінням можливості не існування в наступний момент чи кінцевості людського життя (на думку С. Кьєркегора, цитовану Р. Меєм), але й «прагнення до щастя ніколи не буде сильнішим, ніж коли необхідно обира- 
ти між днем сьогоднішнім і завтрашнім, оскільки післязавтра всі ці пошуки все одно завершаться» [8].

У процесі життя людини зв'язок цих понять може не усвідомлюватися, можна бути цілком задоволеним життям, навіть щасливим, i не шукати ((не знати), що життя може (повинне) мати) сенс; можна наполегливо шукати сенс, не відчуваючи задоволення від життя; так само, можна прагнути реалізувати життєвий сенс і робити це, переживаючи важкі і непрості часи, при цьому не будучи задоволеним життям чи щасливим; i, на нашу думку, коли людина починає задумуватися про сенс життя, вона вочевидь не відчуває задоволення життям у повній мірі (ій чогось не вистачає).

Тільки в кінці життя, при підведенні підсумків минулого життєвого шляху і своїх досягнень, ці феномени стають зіставними : задоволення від пройденого життєвого шляху переживається, якщо мета життя досягнута, сенс - знайдений, усвідомлений і адекватно реалізований.

К.О. Абульханова-Славська зазначає, що задоволеність чи незадоволеність життям «складне, але завжди узагальнене почуття», щодо того, чи склалося життя людини, чи вдале воно (по суті, чи реалізований сенс життя). Це почуття є «важливим показником особистісних досягнень» [1]. I лише сама людина може суб'єктивно оцінити власне життя за цим критерієм.

Вчена акцентує на тому, що надто ви- сока психологічна ціна, затрачена на життєві досягнення, знижує мотивацію людини і підриває сенс ії життя. Проте, за умови надто малої ціни, коли успіх приходить без усяких зусиль з боку особистості, людина також перестає відчувати задоволення, а це, в свою чергу, руйнує сенс іiі життя. I лише, коли можливостям особистості пропорційна міра зусиль, дій, затрат, вона відчуватиме справжню задоволеність життям, і нею живитиметься подальший сенс іiі життя [1, с.74].

Сенс життя, за В. Е. Чудновським, «певна ідея, що містить мету життя людини і стала для неї цінністю надзвичайно високого порядку» [17]. Знайдення сенсу дозволяе людині сприймати життя не як суму окремих епізодів і подій, а уявити собі «життєвий простір особистості» певною цілісністю і відповідно до цього намічати і реалізовувати власні ідеї [17]. Із сенсом людина отримує і особливе ставлення до часу життя, розуміє його незворотність, розвиває в собі прагнення до його раціонального використання - людина не може, не повинна, на думку В. Е. Чудновського, прожити життя у вигляді «чорнового начерку», оскільки не буде часу «переписати» його начисто. Нарешті, складність знайдення сенсу життя у тому, щоб відшукати його «серед множини проявів безглуздості життя» [17].

В. Е. Чудновський також вводить поняття «оптимального» життєвого сенсу, який, на його думку, «можна охарактеризувати як гармонійну структуру смисложиттєвих орієн- 
тацій, що істотно обумовлюють високу успішність у різних сферах діяльності, максимальне розкриття здібностей та індивідуальності людини, іiї емоційний комфорт, що проявляється у переживанні повноти життя і задоволеності ним» [16]. Тобто оптимальний життєвий сенс пов'язується 3 переживанням задоволеності життям.

Не вдаючись до критичного аналізу цього визначення В. Е. Чудновського, зазначимо, що при такому розумінні оптимального (найкращого для самої людини) сенсу життя він може зустрічатися ще рідше, ніж самоактуалізовані особистості (згідно А. Маслоу), як і задоволеність життям («обумовлена» таким сенсом). Значно більш прийнятним виглядає підсумкове визначення вченого щодо оптимального сенсу життя, суть якого В. Е. Чудновський бачить «в органічному поєднанні задовольняючої людину життєвої мети і задоволення, отримуваного від самого процесу іiі реалізації, від «сьогоднішніх іiі результатів», першоосновою чого є “загальнолюдська моральність”» [16]. На нашу думку, сенс має узгоджуватися з призначенням людини у світі, іiі долею, але призначення людини може не завжди нести добро навіть для неї самої, і навряд чи тут можна говорити про «оптимальність» сенсу взагалі. Додамо, що І. Бонівелл ситуацію пояснює простіше: «людина задоволена, коли майже відсутній розрив між існуючим положенням і тим, що представляється їй ідеальною ситуацією або такою, яку вона заслу- жила» [5].

Сенс «проектує» для людини кращу дійсність, те, яким життя має стати. Специфіка ж сенсу в тому, що в його змісті відображається не стільки реальну життєву ситуацію, скільки бажану і можливу, майбутній стан буття особистості - у такому випадку наявність сенсу не вичерпує причин задоволеності життям (бути задоволеним можна й у теперішньому часі, і навіть не думаючи про сенс), скоріше, відсутність і пошуки сенсу - результат невдоволеності тим, що $є$.

Заслуговує на увагу думка Ш. Стайл, що саме мета життя дає нам причину прагнути до чогось. Вона стимулює нас рухатися до більш цікавих цілей, пов'язаних із самореалізацією, дозволяючи тим самим відчути евдемонічне щастя, а також почуття задоволення $\mathrm{i}$ визначеного шляху в житті [11].

3 подачі В. Франкла, наявність сенсу життя сприймається як умова особистісного задоволення життям. Тому К. В. Карпінський вважає суб'єктивну задоволеність життям одним з психологічних критеріїв оптимальності життєвої стратегії особистості, визначаючи задоволеність життям як «узагальнене емоційне переживання, що забарвлює сприйняття індивідуального життя в цілому і відображає міру процвітання (успіху), прогресу, просування особистості у реалізації життєво значимих цінностей, мотивів, цілей» [7]. Тобто життя людини можна вважати задовільним і щасливим лише тоді, коли продуктивно здійсню- 
ється ії особистісний сенс, реалізуються життєві цілі, плани і програми [7]. Цьому допомагає оптимальна життєва стратегія (вона збільшує досягнення, водночас зменшуючи затрати, дозволяючи збалансувати успіхи та невдачі на життєвому шляху особистості), завдяки якій сенс життя реалізується за ту ціну, що «адекватна масштабу і складності цього сенсу» [6]. На думку вченого, «за інтенсивністю і динамікою почуття задоволеності» можна зробити висновок про характер практичної реалізації життєвого сенсу.

Цікаво, що науковці в основному зосереджують увагу на тих затратах, які випадуть людині на долю на життєвому шляху в спробі здійснити сенс і відчути задоволеність від результатів процесу. Тоді як, на наш погляд, не менш важливим фактором відчуття задоволеності життям (і за умови реалізації його сенсу) $\epsilon$ час: для відчуття задоволення (справжнього і повноцінного) від будь-чого (від здійснення бажання та досягнення поставленої мети - до втілення сенсу життя) важливо, щоб це відбулося вчасно, в іншому випадку (коли людина вже й останню надію втратила, що отримає бажано-необхідне) - задоволення, якщо i з'явиться, то у «редукованому» варіанті: значно слабше і більш короткочасне від передбачуваного початково. Тобто, незалежно від масштабу докладених зусиль, якщо людина отримає бажане повною мірою, але значно пізніше, ніж хотілося чи передбачалося (ніж вона готова була чекати), воно знеціниться, за суттю, переставши бути бажаним, чи, принаймні, стане менш бажаним (буденним), відповідно, це вплине на відчуття задоволеності досягнутим (отриманим) результатом.

У дослідженні рівня задоволеності життям студентів-третьокурсників - майбутніх психологів ( $\mathrm{n}=30)$, ми використали методики: «Втрати та здобутки персональних ресурсів» (Н. Водоп'янова, М. Штейн), Оксфордський опитувальник щастя, методика на відчуття безпеки (Р. Янов-Бульман, адаптація О. Кравцової), тест СЖО (О. М. Леонтьєва), методика здатності до самоуправління (Н. М. Пейсахова).

За опитувальником «Втрати та здобутки персональних ресурсів» [9], ресурси розуміються як ті життєві цінності, що допомагають людині справлятися з проблемами життя. Ними, згідно авторів методики, можуть бути матеріальні та нематеріальні засоби, зовнішні та внутрішні, «стан душевного та фізичного благополуччя», енергетичні характеристики, необхідні для життя. На думку С. Хобфолла, який створив ресурсну концепцію стресу, його ризик збільшується при порушенні балансу між втратами і набуттям персональних ресурсів. Причому стрес тлумачиться в основному як результат неспівпадання бажаного і можливого для людини. Зазначимо, що, з одного боку, за К. О. Абульхановою-Славською, таке неспівпадання може супроводжуватися знеціненням життєвого сенсу для особистості, 3 іншого, - будова методики спонукає асоцію- 
вати їі результати з переживанням респондентами позитивних i негативних емоцій, які включені, за Е. Дінером, у структуру суб'єктивного благополуччя.

Аналіз середніх по вибірці засвідчує незначне переважання втрат над життєвими здобутками опитаних (98,6 та 86 балів відповідно), проте ця різниця може сприйматися як суттєва в контексті думки авторів методики щодо нерівнозначності здобутків і втрат для людини, якій необхідна не лише відсутність втрат своїх життєвих цінностей, але, власне, нові здобутки.

Індекс рівня ресурсності (співвідношення між здобутками і втратами) у переважної більшості студентів $(66,67 \%)$ - на середньому рівні, ще у 26,67 \% - він високий та у $6,67 \%$ опитаних - низький; тобто у більшості опитаних число здобутків і втрат відносно врівноважене, у декого - життєві здобутки значно перевищують втрачене, що дає їм привід переживати задоволеність життям, і тільки у 6,67 \% студентів відчутно переважають втрати життєвих ресурсів, мотивуючи переживання невдоволеності життям.

За Оксфордським опитувальником щастя, серед опитаних переважають особи із середнім рівнем показника (70 \%), найменше студентів з пониженим (10\%), дещо більше 3 підвищеним (20\%) показником щастя у житті, отже, і переживанням задоволеності ним.

Здатністю управляти собою у нових ситуаціях з новими цілями (де самоуправління врозуміється як цілеспрямована зміна людини згідно власної мети та здійснення власного керівництва своєю активністю у будь-яких формах), опитані володіють переважно у середньому (у 60 \%) та вище середнього (33,33 \%), у решти досліджуваних - низький та нижче середнього рівні розвитку здатності до самоуправління, отже, в опитаних присутня достатньо цілісна, але не остаточно сформована система самоуправління; сприятливим видається факт, що студенти, залежно від ситуації, керуються емоціями та раціональністю, адекватно справляючись зі своїми проблемами і невдачами; серед ланок самоуправління в опитаних найліпше сформовані етапи аналізу протиріч $\mathrm{i}$ орієнтації в ситуації (середня - 4 бали), прогнозування (3,8 балів) та прийняття рішення (3,7 балів), тоді як дещо відстають у розвитку етапи планування й оцінки (3 та 3,1 балів відповідно) - вибір критеріїв оцінки зробленого та досягнутого.

За тестом на почуття безпеки, опитані найбільше вірять у цінність свого Я й адекватність власної поведінки (середня - 4,86 балів), тоді як найменше досліджувані схильні сприймати навколишній світ як осмислений $(3,56$ балів), а події - як результат випадковості $(3,1$ бали).

Згідно результатів методики СЖО, досліджувані сприймають власне життя як достатньо осмислене (середня - 146 балів), менше задоволені результатами минулої самореалізації, продуктивністю прожитої частини життя, 
досягнутим, ніж емоційною насиченістю і зацікавленістю теперішнім життям і його наповненістю сенсом (середні - 27 та 31,7 балів), мають мету в житті, орієнтуються на майбутню перспективу (32,4 балів); показник локусу контролю - життя переважає локус контролю - Я (середні - 32,8 та 22 балів відповідно), тобто студенти більше переконані у власній здатності контролювати події свого життя, втілюючи прийняті рішення, ніж в уявленні себе сильною особистістю, здатною будувати власне життя відповідно до поставленої мети і бачення його сенсу (хоча в окремих студентів (36,67 \%) ситуація протилежна).

За результатами кореляційного аналізу, відчуття щастя (задоволення життям) виявляє статистично значимі кореляційні зв'язки зі складовими самокерування: прогнозуванням $(\mathrm{r}=0,36)$, оцінкою $(\mathrm{r}=0,36)$, цілепокладанням $(\mathrm{r}=0,36)$, аналізом протиріч $(\mathrm{r}=0,36)$, самоуправлінням в цілому $(\mathrm{r}=0,37)$; базовими переконаннями у тому, що світ повний сенсу $(\mathrm{r}=$ $0,42)$ та в цінність власного Я $(\mathrm{r}=0,37)$, вірою в свою удачливість $(\mathrm{r}=0,45)$, довірою до справедливості світу $(\mathrm{r}=0,40)$; зі здобутками персональних ресурсів протягом життя опитаних $(\mathrm{r}=0,53)$ і рівнем ресурсності $(\mathrm{r}=0,36)$; осмисленістю теперішнього життя $(\mathrm{r}=0,36)$, локусом контролю - Я $(\mathrm{r}=0,38)$, локусом контрою - життя $(\mathrm{r}=0,36)$. Зазначимо, що всі коефіцієнти свідчать про слабку кореляцію, що, зокрема, може пояснюватися величиною вибірки.

Висновки. Отже, задоволення життям є результатом вдалої, успішної реалізації людиною ії життєвої мети, яка сприймається як надважлива екзистенційна цінність, життєвий сенс. Людина, задоволена життям і живучи 3 відчуттям щастя, наївно-оптимістично вірить у справедливість світу і власну фортуну; сподівається на достатній рівень (психологічний і енергетичний) персональних життєвих ресурсів, що реалізуються в осмисленому житті (що не виключає критичної оцінки щодо наявності сенсу в світі у цілому), переконані у своїй здатності раціонально ставити і досягати цілей для здійснення сенсу життя завдяки контролю за подіями власного життя та розвитку здатності до самоуправління.

\section{Перспективу подалышого досліджен-}

ня вбачаємо у вивченні зв'язку між психологічним благополуччям (складовою якого є задоволеність життям) і смисложиттєвими орієнтаціями особистості.

\section{Перелік використаних джерел:}

1. Абульханова-Славская К. А. Стратегия жизни / К.А. Абульханова-Славская. - М. : Мысль, 1991. - 299 с.

2. Андреенкова Н. В. Сравнительный анализ удовлетворенности жизнью и определяющих ее факторов [Электронный ресурс] / Н.В. Андреенкова // Мониторинг общественного мнения: экономические и социальные перемены. - 2010. - № 5 (99). - С.189-215. - Режим доступа: https://cyberleninka.ru/article/n/sravnitelnyyanaliz-udovletvorennosti-zhiznyu-i-opredelyayuschih-eefaktorov.

3. Аргайл М. Психология счастья / М. Аргайл. - 2-е изд. - СПб.: Питер, 2003. - 271 с. - (Серия «Мастера психо- 
логии»).

4. Балацкий E. В. Факторы удовлетворенности жизнью: измерение и оценка [Электронный ресурс] / Е.В. Балацкий. - Режим доступа: http://kapital-rus.ru/articles/ article/

faktory_udovletvorennosti_zhiznyu_izmerenie_i_ocenka/.

5. Бонивелл И. Ключи к благополучию: Что может позитивная психология / И. Бонивелл; пер. с англ. М. Бабичевой. - М.: Время, 2009. - 192 с.

6. Карпинский K. В. Стратегия жизни как структурная организация индивидуальной жизнедеятельности / К.В. Карпинский // Психология жизненного пути личности : методологические, теоретические, методические и прикладные проблемы : сб. науч. ст. - Гродно : ГрГУ, 2012. - C.301-337.

7. Карпинский К. В. Ценностные конфликты и смысложизненный кризис в развитии личности [Электронный ресурс] / К.В. Карпинский // Психологические исследования: электрон. науч. журн. - 2011. - № 5 (19). - Режим доступа : http://psystudy.ru/num/2011n5-19/553karpinskii19.

8. Мэй Р. Открытие бытия / Ролло Мэй. - М.: Институт общегуманитарных исследований, 2016. - 224 с. (Современная психология: теория и практика).

9. Опросник Потери и приобретения персональных ресурсов (Тест ОППР), Н. Водопьянова, М. Штейн [Электронный ресурс]. - Режим доступа : http:// psychok.net/testy/516-oprosnik-poteri-i-priobreteniyapersonalnykh-resursov-test-oppr-n-vodopyanova-m-shtejn. 10. Психологический словарь / Под общей науч. ред. П.С. Гуревича. - М.: ОЛМА Медиа Групп, ОЛМА ПРЕСС Образование, 2007. - 800 с.

11. Стайл Ш. Позитивная психология. Что делает нас счастливыми, оптимистичными и мотивированными / Ш.Стайл. - М.: Претекст, 2013. - 326 с.

12. Тест индекс жизненной удовлетворенности (ИЖУ), адаптация Н.В. Паниной. Опросник общего психологического состояния человека [Электронный ресурс]. Режим доступа : http://psychok.net/testy/506-test-indekszhiznennoj-udovletvorennosti-izhu-adaptatsiya-n-v-paninoj -oprosnik-obshchego-psikhologicheskogo-sostoyaniyacheloveka.

13. Углова T. В. Субъективные предпосылки удовлетворенности жизнью в период взрослости [Электронный pecypc] / Т.В. Углова // Вестник НГУ. - 2013. - Т.2. - № 74. - С.91-94. - Режим доступа : https://cyberleninka.ru/ article/n/subektivnye-predposylki-udovletvoryonnostizhiznyu-v-period-vzroslosti.

14. Удовлетворенность [Электронный ресурс]. - Режим доступа : http://enc-dic.com/enc_psy/ Udovletvorennost-28311/.

15. Франкл В. Человек в поисках смысла / В.Франкл. М.: Прогресс, 1990. - 372 с. - (Библиотека зарубежной психологии).

16. Чудновский В. Э. Проблема оптимального смысла жизни [Электронный ресурс] / В.Э. Чуд-но-вский // Психология и школа : научно-методический журнал / Ред. А.Г. Лидерс. - 2015. - № 1. - 2015. - С. 100-117. Режим доступа : http://akme31.narod.ru/1.html.

17. Чудновский В. Э. Смысл жизни и судьба человека [Электронный pecypc] / В.Э. Чудновский // Общественныей науки и современность. Культура. - 1998. № 1. - С.175-183. - Режим доступа : http:// ecsocman.hse.ru/data/154/128/1218/017Chudnovskij.pdf.

18. Шамионов Р. М. Психология субъективного благополучия личности [Электронный ресурс] / Р.М. Шамионов. - Саратов : Изд-во Сарат. ун-та, 2008. - 296 с. Режим доступа : http://psylib.myword.ru/index.php? automodule $=$ downloads $\&$ showfile $=1259$.

19. Lucas R. E. Personality and Subjective Well-Being / R.E. Lucas, E. Diener // Handbook of personality : theory and research / edited by O.P. John, R.W. Robins, L.A. Pervin. $-3^{\text {rd }}$. ed. - New York-London: Guilford Press, 2010. - P.795-814.

\section{References (Transliteration):}

1. Abul'hanova-Slavskaja K. A. Strategija zhizni / K.A. Abul'hanova-Slavskaja. - M. : Mysl', 2004. - 299 s. 
2. Andreenkova N. $V$. Sravnitel'nyj analiz udovletvorennosti zhizn'ju i opredeljajushhih ee faktorov [Jelektronnyj resurs] / N.V. Andreenkova // Monitoring obshhestvennogo mnenija: jekonomicheskie i social'nye peremeny. - 2010. № 5 (99). - S.189-215. - Rezhim dostupa: https:// cyberleninka.ru/article/n/sravnitelnyy-analizudovletvorennosti-zhiznyu-i-opredelyayuschih-ee-faktorov. 3. Argajl M. Psihologija schast'ja / M. Argajl. - 2-e izd. SPb.: Piter, 2003. - 271 s. - (Serija «Mastera psihologii»).

4. Balackij E. V. Faktory udovletvorennosti zhizn'ju: izmerenie i ocenka [Jelektronnyj resurs] / E.V. Balackij. Rezhim dostupa: http://kapital-rus.ru/articles/article/ faktory_udovletvorennosti_zhiznyu_izmerenie_i_ocenka/.

5.Bonivell I. Kljuchi k blagopoluchiju: Chto mozhet pozitivnaja psihologija / I. Bonivell; per. s angl. $\mathrm{M}$. Babichevoj. - M.: Vremja, 2009. - 192 s.

6. Karpinskij $K$. $\quad V$. Strategija zhizni kak strukturnaja organizacija individual'noj zhizne-dejatel'nosti / K.V. Karpinskij // Psihologija zhiznennogo puti lichnosti : metodologicheskie, teore-ticheskie, metodicheskie i prikladnye problemy : sb. nauch. st. - Grodno : GrGU, 2012. - S.301-337.

7. Karpinskij $\quad K . \quad$ V. $\quad$ Cennostnye konflikty i smyslozhiznennyj krizis $\mathrm{v}$ razvitii lichnosti [Jelektronnyj resurs] / K.V. Karpinskij // Psihologicheskie issledovanija: jelektron. nauch. zhurn. - 2011. - N 5 (19). - Rezhim dostupa: http://psystudy.ru/num/2011n5-19/553karpinskii19.

8. Mjej R. Otkrytie bytija / Rollo Mjej. - M.: Institut obshhegumanitarnyh issledovanij, 2016. - 224 s. (Sovremennaja psihologija: teorija i praktika).

9. Oprosnik Poteri i priobretenija personal'nyh resursov (Test OPPR), N. Vodop'janova, M. Shtejn [Jelektronnyj resurs]. - Rezhim dostupa : http://psychok.net/testy/516oprosnik-poteri-i-priobreteniya-personalnykh-resursov-testoppr-n-vodopyanova-m-shtejn.

10. Psihologicheskij slovar / Pod obshhej nauch. red. P.S. Gurevicha. - M.: OLMA Media Grupp, OLMA PRESS Obrazovanie, 2007. - $800 \mathrm{~s}$.

11. Stajl Sh. Pozitivnaja psihologija. Chto delaet nas schastlivymi, optimistichnymi i motivirovannymi / Sh.Stajl. - M.: Pretekst, 2013. - 326 s.

12. Test indeks zhiznennoj udovletvorennosti (IZhU), adaptacija N.V. Paninoj. Oprosnik obshhego psihologicheskogo sostojanija cheloveka [Jelektronnyj resurs]. - Rezhim dostupa : http://psychok.net/testy/506test-indeks-zhiznennoj-udovletvorennosti-izhu-adaptatsiyan-v-paninoj-oprosnik-obshchego-psikhologicheskogosostoyaniya-cheloveka.

13. Uglova $\quad T$. $\quad$. Sub\#ektivnye predposylki udovletvorennosti zhizn'ju v period vzroslosti [Jelektronnyj resurs] / T.V. Uglova // Vestnik NGU. - 2013. - T.2. - № 74. - S.91-94. - Rezhim dostupa : https://cyberleninka.ru/ article/n/subektivnye-predposylki-udovletvoryonnostizhiznyu-v-period-vzroslosti.

14. Udovletvorennost [Jelektronnyj resurs]. - Rezhim dostupa : http://enc-dic.com/enc_psy/Udovletvorennost$28311 /$.

15. Frankl V. Chelovek v poiskah smysla / V.Frankl. - M.: Progress, 1990. - 372 s. - (Biblioteka zarubezhnoj psihologii).

16. Chudnovskij V. E. Problema optimal'nogo smysla zhizni [Jelektronnyj resurs] / V.E. Chudnovskij // Psihologija i shkola : nauchno-metodicheskij zhurnal / Red. A.G. Liders. - 2015. - № 1. - 2015. - S. 100-117. - Rezhim dostupa : http://akme31.narod.ru/1.html.

17. Chudnovskij V. E. Smysl zhizni i sud'ba cheloveka [Jelektronnyj resurs] / V.E. Chudnovskij // Obshhestvennyej nauki i sovremennost'. Kul'tura. - 1998. № 1. - S.175-183. - Rezhim dostupa : http:// ecsocman.hse.ru/data/154/128/1218/017Chudnovskij.pdf.

18. Shamionov R. M. Psihologija sub\#ektivnogo blagopoluchchja lichnosti [Jelektronnyj resurs] / R.M. Shamionov. - Saratov : Izd-vo Sarat. un-ta, 2008. - 296 s. Rezhim dostupa : http://psylib.myword.ru/index.php? automodule $=$ downloads \&showfile $=1259$.

19. Lucas R. E. Personality and Subjective Well-Being / R.E. Lucas, E. Diener // Handbook of personality : theory and research / edited by O.P. John, R.W. Robins, L.A. Pervin. $-3^{\text {rd }}$. ed. - New York-London: Guilford Press, 
2010. - P.795-814.

\section{Chuyko Halyna}

PhD in philological sciences, associate professor of psychology department, Yuriy Fedkovych Chernivtsi National University, Chernivtsi (Ukraine)

\section{THE MEANING OF LIFE IN THE CONTEXT OF THE FEELING OF LIFE SATISFACTION}

\section{ABSTRACT}

The article analyzes the phenomenon of life satisfaction and its relationship with the meaning of life and life purport orientations in theoretical and empirical aspects.

It is noted that while E. Diner considered that life satisfaction is the cognitive component of subjective well-being feeling (which, in his opinion, corresponds to the concept of "happiness"), most psychologists who have studied this concept, and we agree with them, tend to see an essential emotional component into its content.

It is noted that the concept of life satisfaction combines the cognitive and emotional aspects of the subjective assessment of a person of the degree of matching of his life to the desirable. The understanding of life satisfaction as a result of successful implementation of human life goal, which is considered as extremely important existential value that gives meaning to human life is determined.

It points out, that people aspire to happiness and enjoyment from life, and see the meaning of not only their own life (in general), but also the sense of life situations, every moment of life, exactly in achievement of this, although more often person does not realize the connection of meaning of life with the sense of life satisfaction till the moment of summing up the results of life path. While V. Frankl argued, that the aspiration for happiness and life satisfaction can't be the meaning of human life, and as well as selfrealization is "by-product" of realization of the meaning of life.

The idea that the meaning of life related to feeling life satisfaction is substantiates. Even in the context of V. Frankl's views the life satisfaction could be interpreted as meaning of life, if correlative with existential values that are able (by Frankl) to make life meaningful.

As a result of empirical research of the degree of satisfaction with life and its meaningfulness by students-psychologists it concludes that the person, satisfied with life and living with a senses of success in the process of realizing its purpose and happiness, believe in the justice of the world and his own fortune; hope for the sufficient level of personal living resources (psychological and energetic) implemented in meaningful life (this don't except a critical assessment of the availability of sense in the world in general) convinced of their ability to rationally raise and achieve goals for the implementation of the meaning of life by controlling the events of his life and development of ability to the selfmanagement.

Key words: life satisfaction, meaning of life, well-being, value, self-management. 


\section{Чуйко Галина Васильевна}

Кандидат филологических наук, доиент, доиент кафедры психологии Черновицкого начионального университета имени Юрия Федьковича, Черновиь (Украина)

\section{СМЫСЛ ЖИЗНИ В КОНТЕКСТЕ ОЩУЩЕНИЯ УДОВЛЕТВОРЕННОСТИ ЖИЗНЬЮ}

Аннотация. В статье анализируется феномен удовлетворенности жизнью и его связь со смыслом жизни и смысложизненными ориентациями личности в теоретическом и эмпирическом аспектах.

Констатируется, что, хотя Э. Динер считал удовлетворенность жизнью когнитивным компонентом ощущения субъективного благополучия (которое, он считает, соответствует и понятию «счастье»), большинство психологов, изучавших данное понятие, и мы согласны с ними, склонны видеть в его содержании существенный эмоциональный компонент.

Показано, что понятие удовлетворенности жизнью объединяет когнитивный и эмоциональный аспекты субъективной оценки человеком степени соответствия его жизни желаемой. Определяется понимание удовлетворения жизнью как результата успешной реализации человеком его жизненной цели, которая рассматривается как сверхважная экзистенциальная ценность, придающая жизни человека смысл.

Отмечается, что люди хотят счастья и удовольствия от жизни, и именно в достиже- нии этого видят смысл не только собственной жизни (в целом), но и смысл жизненных ситуаций, каждого момента жизни, однако чаще человек не осознает связи смысла жизни с ощущением удовлетворенности от жизни до момента подведения итогов жизненном пути. Тогда как В. Франкл утверждал, что стремление к счастью и удовлетворенность жизнью не может быть смыслом жизни человека, а, как и самореализация, является «побочным» продуктом осуществления жизненного смысла.

Обосновывается мнение, что смысл жизни и переживания удовлетворенности жизнью связаны. И даже в контексте взглядов В. Франкла удовлетворенность жизнью может восприниматься как жизненный смысл в случае соотнесения с экзистенциальными ценностями, которые способны (по Франклу) сделать жизнь человека осмысленной.

В результате эмпирического исследования степени удовлетворенности жизнью и его осмысленности студентами-психологами делается вывод, что человек, удовлетворенный жизнью, живя с ощущениями успешности процесса реализации его цели и счастья, верит в справедливость мира и собственную удачу; надеется на достаточный уровень персональных жизненных ресурсов (психологических и энергетических), реализуемых в осмысленной жизни (что не исключает критической оценки наличия смысла в мире в целом), убеждены в своей способности рационально ставить и достигать целей для осуществления смысла жиз- 
ни благодаря контролю над событиями своей жизни и развития способности к самоуправлению.

Ключевые слова: удовлетворенность жизнью, смысл жизни, благополучие, ценности, самоуправление. 